is prolonged and thorough, and it is shown that for each type there is the possibility and the promise of a successful career.

\section{What are Comets?}

Cienciae Investigación No. 2, February 1945, contains an article with the title "¿Qué son los cometas?" by Enrique Gaviola, director of the Córdoba Observatory, which gives a short account of comets from ancient times up to the present. There is nothing new in the article, but it provides a useful summary of our knowledge of these visitors, dealing with the spectrograms of the gases in the head and tail, the masses deduced by the perturbations or lack of perturbations produced by comets, changes in luminosity due to varying distances from the sun, light pressure on the smaller particles, etc. The author conjectures that the asteroids were once brilliant comets-a view which is entertained by others, but lacking in conclusive evidence. There is a very fine photograph of Halley's Comet taken at Córdoba Observatory on May 7, 1910.

\section{Recent Earthquakes}

During January 1945, ten earthquakes were registered at the seismological observatory at Toledo, Spain. The greatest of these was on January 12, when an earthquake, registering initially at $18 \mathrm{~h} .52 \mathrm{~m}$. 0 ls. G.м.T., developed an amplitude of $50 \mu$ at $19 \mathrm{~h}$. $36 \mathrm{~m}$. 13s. G.M.T. on the east-west component. The epicentral distance has been provisionally estimated at $12,830 \mathrm{~km}$. During the same month one strong distant earthquake was registered at the Dominion Observatory, Wellington, New Zealand. This was on January 28 at $07 \mathrm{~h}$. $37 \mathrm{~m}$. 18s. G.M.T. from an epicentral distance of approximately $22^{\circ}$. The shock was also registered at Christchurch, Auckland and Arapuni. In New Zealand there were twelve shocks humanly felt in the Dominion during the month. The greatest of these was on January 2 . It was felt with intensity 5 (Modified Mercalli Scale) in the North Island, south of Wairo Taupo and Wanganui. On January 1 a shock was also felt at Wairo with intensity 5 (Mod. Mer.). The United States Coast and Geodetic Survey, in co-operation with Science Service and the Jesuit Seismological Association, has determined the provisional epicentre of the earthquake of January 12 to be near lat. $34^{\circ} \mathrm{N}$, long. $139^{\circ} \mathrm{E}$., which is off the coast of Japan, to the south of Tokyo.

During February 1945, fourteen strong earthquakes were registered at the observatory at Toledo, Spain. The strongest of these occurred on February 10 and registered at Toledo at 05h. 11m. 09s. G.M.T., attaining a maximum ground amplitude at Toledo of $115 \mu$ on the north-south component at $05 \mathrm{~h} .50 \mathrm{~m}$. 35s. G.M.T. The epicentral distance is estimated at $10,440 \mathrm{~km}$. The shock of February 20 is estimated to have had its epicentre $660 \mathrm{~km}$. from Toledo. The earthquake of February 18 was recorded at Kew, as was also that of February 26. The United States Coast and Geodetic Survey, in co-operation with Science Service and the Jesuit Seismological Association, has determined the provisional epicentre of the earthquake of February 10, from instrumental reports from twenty-one observatories, to have been at lat. $41 \cdot 5^{\circ} \mathrm{N}$., long. $142^{\circ} \mathrm{E}$., which is off the coast of Japan to the east of Hakodate. The initial time was $4 \mathrm{~h} .57 \cdot 9 \mathrm{~m}$. G.M.T.

During March 1945, Mr. E. W. Pollard recorded seven earthquakes at his observatory at Binstead, Isle of Wight. Three occurred on March 18.

\section{The Film in Science}

The Scientific Film Association is holding a conference on "The Film in Science" at the Technical College, Huddersfield, during August 31--September 2. The opening address will be given by Mr. Arthur Elton, president of the Association, and there will be sessions on the film in education, industry and medicine, and as an instrument of research. Dr. W. T. Astbury will give a lecture on the X-ray examination of proteins. There will be a display of visual aid equipment. Registration forms to attend the conference, and further particulars, can be obtained from the secretary of the Association, e/o Royal Photographic Society, 16 Princes Gate, London, S.W.7.

\section{United Nations Educational Conference in London}

A CONFERENCE is to be held in London on November I next to consider the establishment of a United Nations Educational and Cultural Organization. The Conference of Allied Ministers under the chairmanship of Mr. Richard Law, Minister of Education, at a meeting in London on July 12, unanimously agreed that the British Government be asked to invite on its behalf the Governments of all the United Nations to send delegates to this conference. A working committee will be set up in London to make preparations for the conference and to assemble and collate opinions and proposals as to the scope and methods of operation of the organization. Draft proposals for the constitution of the organization, prepared by the Conference of Allied Ministers, will be issued shortly and will form the basis of discussion at the forthcoming conference.

\section{Announcements}

Dr. Arexander S. Wrener, of New York University, has been awarded the Alvarenga Prize for 1945 of the College of Physicians of Philadelphia, "in recognition of his important work upon the various types of Rh factors and on their genetic transmission". Dr. Wiener will give the Alvarenga Lecture before the College of Physicians of Philadelphia and the Philadelphia County Medical Society on October 3, 1945, on " $R h$ Blood Factors in Clinical Medicine". This Prize was established by the will of Pedro Francisco daCosta Alvarenga of Lisbon, Portugal, an associate fellow of the College of Physicians of Philadelphia, "to be awarded annually by the College of Physicians on each anniversary of the death of the testator, July 14, 1883". The College usually makes this award for outstanding published work, and invites the recipient to deliver an Alvarenga Lecture before the College.

THe Council of the University of Sheffield has made the following appointments: Dr. H. Motz to be lecturer in engineering physics; Dr. James White to be lecturer in refractory materials in the Department of Metallurgy. Dr. C. Gray Imrie, lecturer in physiology, and Mr. J. MacA. Croll, lecturer in bacteriology, have resigned. Mr. C. H. Hainsworth, lecturer in electrical engineering, and Dr. W. J. Rees, lecturer in refractories, are retiring under the age limit. 'The Yorkshire Mine Workers' Association is to provide two scholarships in 1946, each of an annual value of $£ 180$, open to members of the Association and tenable for a full-time degree course in mining at the University. 